\title{
RETHINKING CRIMINAL HOMICIDE STATUTES: GIVING JURIES MORE DISCRETION
}

\author{
Joshua Dressler*
}

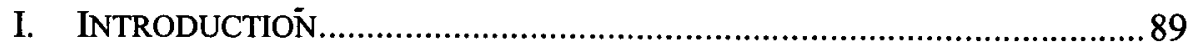

II. ABOLISHING PREMEDITATION-DELIBERATION FORMULA ….............. 92

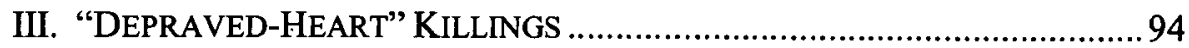

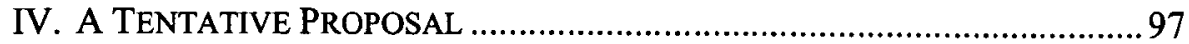

\section{INTRODUCTION}

Today, with all of you great people here, I want to think aloud and offer some very tentative thoughts about how we might recodify our murder statutes. I stress that these thoughts are quite tentative. Sometimes, I am not even sure I agree with myself! So, I hope in coming days and weeks you--and, now, readers of this presentation-will get back to me with your thoughts. I do not want to make a fool of myself or even make plausible but entirely unrealistic suggestions.

As it turns out, this conference comes at a perfect time for me because I have begun working on a book. I have barely started. Indeed, in some ways this is the start. I imagine the title of my book to be something like Killing People. I hope to use the book to think about, and in some cases reconsider, homicide topics about which I have written in the past: provocation, self-defense, killing under duress or out of necessity, and the like. ${ }^{1}$ But, I also

* Distinguished University Professor and Frank R. Strong Chair in Law, Michael E. Moritz College of Law, The Ohio State University. This Article is a very slightly revised version of my lunch presentation at the Criminal Law Symposium on Homicide held at Texas Tech University School of Law on April 4, 2014. I thank Professor and mensch Arnold Loewy, organizer of the conference, for inviting me to give the luncheon presentation. Thanks, also, are due to Lisa Herman and Megan Bracher, my research assistants, for their excellent assistance. Finally, I received various excellent comments on my lunch presentation from others attending the conference. As this, however, is intended to be a near-verbatim account of my April 4 presentation (the revisions consist mostly of the addition of footnotes), their suggestions are not incorporated herein. I will deal with them in the future when my proposed book, Killing People, (hopefully) is completed and published.

1. See generally Joshua Dressler, Battered Women Who Kill Their Sleeping Tormenters: Reflections on Maintaining Respect for Human Life While Killing Moral Monsters, in CRIMINAL LAW THEORY: DOCTRINES OF THE GENERAL PART 259 (Stephen Shute \& A.P. Simester eds., 2002) (discussing self-defense); Joshua Dressler, Reply: Battered Women, Sleeping Abusers, and Political and Moral Theory, in FLETCHER's ESSAYS ON CRIMINAL LAW 225 (Russell Christopher ed., 2013) (discussing self-defense); Joshua Dressler, Duress, in THE OXFORD HANDBOOK OF PHILOSOPHY OF CRIMINAL LAW 269 (John Deigh \& David Dolinko eds., 201 1 ) (discussing duress); Joshua Dressler, Reflections on Dudley and Stephens and Killing the Innocent: Taking $a$ Wrong Conceptual Path, in THE SANCTITY OF LIFE AND THE CRIMINAL LAW: THE LEGACY OF GLANVILLE WILliams 126 (Dennis J. Baker \& Jeremy Horder eds., 2013) (discussing necessity); Joshua Dressler, 
want to use the book to consider a topic about which I have not yet written, namely, my topic for today: how legislatures might go about distinguishing different levels of criminal homicide. For today, given my limited time, I will only consider murder (not manslaughter), ${ }^{2}$ make some general points, and set out my preliminary thoughts on this topic.

Let me begin by laying out basic premises that guide me. First, we should distinguish between criminal homicide offenses on the basis of retributive, just-deserts criteria - on the basis of social harm caused and, in particular, one's culpability for causing the harm-rather than on the basis of differential degrees of future dangerousness (although, of course, retributive and utilitarian approaches may sometimes happily overlap). This just-deserts approach should come as no surprise, nor be all that controversial, for this is the way we have distinguished murder from manslaughter for centuries (and, more recently, the way we have distinguished degrees of murder), and here I agree entirely with the traditional approach. ${ }^{3}$

The second premise involves a defendant's Sixth Amendment right to trial

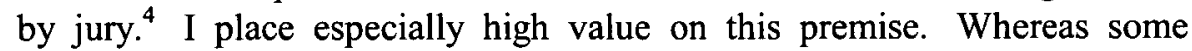
constitutional rights potentially undermine the accuracy of criminal trials in order to enhance some other value, ${ }^{5}$ I view trial by jury not only as a right that the defendant obviously possesses, but also as an institution that provides a great collateral benefit to the community as a whole. After all, most criminal trials (or plea bargains) only occasionally involve the basic factual determination of whether the police arrested the right person. Most prosecutions involve factual issues such as mens rea, motive, and the like, as

Rethinking Heat of Passion: A Defense in Search of a Rationale, 73 J. CRIM. L. \& CRIMINOLOGY 421 (1982) (discussing provocation manslaughter); Joshua Dressler, Why Keep the Provocation Defense?: Some Reflections on a Difficult Subject, 86 MINN. L. REV. 959 (2002) (discussing provocation manslaughter); Joshua Dressler, Battered Women and Sleeping Abusers: Some Reflections, 3 OHIO ST. J. CRIM. L. 457 (2006) (discussing self-defense); Joshua Dressler, Feminist (or "Feminist") Reform of Self-Defense Law: Some Critical Reflections, 93 MARQ. L. REV. 1475 (2010) (discussing self-defense); Joshua Dressler, Exegesis of the Law of Duress: Justifying the Excuse and Searching for Its Proper Limits, 62 S. CAL. L. REV. 1331 (1989) (discussing duress).

2. Thus, I am offering only half of the solution. There will be more to come.

3. But see, Michael J. Zydney Mannheimer, Not the Crime but the Cover-Up: A Deterrence-Based Rationale for the Premeditation-Deliberation Formula, 86 IND. L.J. 879, 881 (2011) (contending that "[w]hether or not intentional murderers who also premeditate and deliberate are the most dangerous and culpable killers, they are the most deterrable," and justifying this distinction between first- and second-degree murder on the basis of deterrence).

4. "In all criminal prosecutions, the accused shall enjoy the right to a speedy and public trial, by an impartial jury ...." U.S. CONST. amend. VI. Although the Amendment seemingly entitles a person charged with a crime to a jury trial in "all criminal prosecutions," the Supreme Court has limited the jury right to prosecutions for which the maximum punishment exceeds incarceration of six months. See Baldwin v. New York, 399 U.S. 66, 69 (1970).

5. For example, the Fourth Amendment prohibition on unreasonable searches and seizures is intended to limit overreaching by government agents in criminal investigations. See Davis v. United States, $131 \mathrm{~S}$. Ct. 2419,2423 (2011). The Supreme Court's traditional remedy for a violation of our rights in this regardexclusion at trial of the fruits of the violation - has the effect of denying the jury reliable evidence of the defendant's guilt, but is considered a justifiable outcome if suppression of the evidence will have a substantial deterrent effect on overzealous police officers. See id. at 2427. 
well as normative questions, such as whether the defendant acted like a reasonable person or possessed reasonable beliefs - which is simply to ask whether the jurors might have acted the same way or possessed the same beliefs as the accused in the actor's situation. Criminal trials and sentencing may no longer represent what Professor Stephanos Bibas has described as "cathartic morality play[s]," ${ }^{, 6}$ but it certainly is true that a criminal conviction sends a message to the defendant and the community about what conduct the law and the community consider (or perhaps just what the law or the community considers) acceptable and unacceptable, and whether the person on trial deserves condemnation for any wrongdoing. That is what should distinguish a criminal conviction from a civil judgment. ${ }^{7}$ And, it is the jurors-the representatives of the community-who are best equipped to make that moral judgment. So, I want to give juries as much authority to draw distinctions among different levels of criminal homicide as reasonably and constitutionally possible (assuming, of course, that the jury determines that a criminal homicide occurred and that the accused committed it).

Indeed-let me enhance this point-we know from ample empirical work that even if jurors want to follow the law, which sometimes we also know they do not, they often are unable to understand and, therefore, follow the legalistic instructions they receive from the judge. ${ }^{8}$ Consequently, I am inclined to think it wise to give the juries fewer, not more, legalistically precise instructions on how to distinguish between different levels of criminal homicide.

I am not talking here about the movement in some states to write more juror-friendly instructions, although I favor that. ${ }^{9}$ Rather, I am talking about the way we draft the statutes themselves. I submit for consideration the proposition that we draft our homicide statutes in a manner that gives jurors substantial freedom to draw their own lines between the more- and less-serious levels of

6. Stephanos Bibas, The MaChINERy of Criminal Justice 13 (2012). George C. Thomas offers a fascinating example of how a criminal trial can serve as a morality play, and yet may be a "vessel[] for a more complicated moral message" than one might have assumed. See George C. Thomas III, Criminal Trials as Morality Plays: Good and Evil, 55 ST. LoUIS U. L.J. 1405, 1405-06 (2011) (recounting shocking events ultimately leading to the post-trial lynching of an African-American convicted of the rape of a white woman).

7. See George K. Gardner, Bailey v. Richardson and the Constitution of the United States, 33 B.U. L. REV. 176, 193 (1953).

8. See generally James R. P. Ogloff \& V. Gordon Rose, The Comprehension of Judicial Instructions, in PSYCHOLOGY AND LAW: AN EMPIRICAL PERSPECTIVE 407 (Neil Brewer \& Kipling D. Williams eds., 2005) (reviewing and summarizing the literature); Dennis J. Devine et al., Jury Decision Making: 45 Years of Empirical Research on Deliberating Groups, 7 PSYCHOL. PUB. POL'Y \& L. 622 (2001) (providing a comprehensive review of research published between 1955 and 1999); Joel D. Lieberman \& Bruce D. Sales, What Social Science Teaches Us About the Jury Instruction Process, 3 PSYCHOL. PUB. POL'Y \& L. 589 (1997) (examining the research and observing that juries may reach a decision "incongruent with the law" because of a misunderstanding of legal instructions, intentional rejection of the law in favor of what they perceive as a more just result, or a misunderstanding of the evidence).

9. See generally Nancy S. Marder, Bringing Jury Instructions into the Twenty-First Century, 81 NOTRE DAME L. REV. 449 (2006) (discussing why jury instructions have "eluded" change in the past, and considering innovations in how the instructions are presented to the jury); Peter Tiersma, The Rocky Road to Legal Reform: Improving the Language of Jury Instructions, 66 BROOK. L. REV. 1081 (2001) (summarizing the history of jury instructions and the movement to improve their comprehensibility). 
criminal homicide. I am not entirely confident about this. And my comments here do not apply to the death-penalty phase of homicide trials where, of course, the Constitution requires that jurors' discretion be guided, but rather to the non-capital aspect of our homicide statutes. ${ }^{10}$

One side point before I move on. We clearly over-punish. We put too many people in prison, and those we send to prison we often over-punish by any sensible retributive or utilitarian standard. So, when I think about murder, degrees of murder, and lesser forms of criminal homicide, I do not assume that the punishment that flows from these crimes should be anywhere near as harsh as they are today. But that is a discussion primarily for another time and place.

\section{ABOLISHING PREMEDITATION-DELIBERATION FORMULA}

The first example of where I think homicide law-either the statutes themselves or the way in which courts have interpreted them - goes wrong is the manner by which many states distinguish between intentional killings. For example, a "willful, deliberate, and premeditated killing" is first-degree murder subject to the state's most severe punishment, ${ }^{11}$ whereas an intentional killing that is not both premeditated and deliberate is "merely" second-degree murder, subject to somewhat less severe punishment. ${ }^{12}$ To start with, even if this formula were a wise one-even if it were true that one who thinks long and hard, with coolness of purpose,${ }^{13}$ about a killing before committing it, is always more culpable than one who purposely kills without such prior thought- the fact is that many courts do not apply this standard, although the legislature apparently called for such a distinction.

Too often courts have merged the doctrines of "premeditation" and "deliberation"-properly understood they are separate standards with, respectively, a quantitative element (how much time has elapsed) and a qualitative one (how maturely the actor has reflected on the situation at hand) ${ }^{14}$

10. See Susan Raeker-Jordan, A Pro-Death, Self-Fulfilling Constitutional Construct: The Supreme Court's Evolving Standard of Decency for the Death Penalty, 23 HASTINGS CONST. L.Q. 455, 473 (1996). I would abolish the death penalty, but that is a topic well beyond the scope of this Article.

11. E.g., Mich. COMP. LAWS ANN. § 750.316(1)(a) (West 2014).

12. E.g., MiCH. COMP. LAWS ANN. $\S 750.317$ (West 2014). This assumes that the killing does not fall within the first-degree definition on different grounds, such as that the killing occurred during the commission or attempted commission of an enumerated felony. E.g., MICH. COMP. LAWS $\S 750.316(1)$ (a).

13. "As a number of courts have pointed out, premeditation and deliberation characterize a thought process undisturbed by hot blood." People v. Morrin, 187 N.W.2d 434, 449 (Mich. Ct. App. 1971).

14. "The word deliberate means arrived at or determined upon as a result of careful thought and the weighing of the consideration for and against the proposed course of action." State v. Balderama, 2004NMSC-008, 135 N.M. 329, 88 P.3d 845, 852 (quoting N.M. RULES ANN., UJI 14-201 (2004) (internal quotation marks omitted) (emphasis in original)). The case of Mitchell $v$. State provides an example of a court that rejects this thoughtful approach. See Mitchell v. State, 767 A.2d 844, 855 (Md. 2001) (stating that "the law does not require that deliberation and premeditation be the product of clear and rational thought," and that the test for first-degree murder is "whether there was the deliberation and premeditation-sufficient time to reflect-not the quality ... of the reflection or whether it may have been emotionally based"). 
-into a single, mostly quantitative, concept of little value. ${ }^{15}$ In many states, it is enough that the defendant "formed the specific intent to kill the victim for some length of time, however short, before the murderous act." may say that a premeditated killing is one "done after a period of time for prior consideration," but how much time is that?" ${ }^{17}$ We are told it "cannot be arbitrarily fixed," but it is "[a]ny interval of time between the forming of the intent to kill and the execution of that intent, which is of sufficient duration for the accused to be fully conscious of what he intended." 18 The fact that so many states treat the premeditation-deliberation formula similarly suggests either that the standard cannot be more effectively applied, or that judges dislike the standard and are legislating from the bench. ${ }^{19}$

But, is it a good standard even if applied properly? Not according to a good number of criminal law scholars. ${ }^{20}$ Certainly if we want to draw a line between more- and less-serious murders on the basis of culpability, the distinction is over- and under-inclusive. Consider James Fitzjames Stephen's famous example: a person who, on a sudden whim, throws a child over a bridge into a river to die (assuming, for present purposes, with an intent to kill). ${ }^{21}$ Compare him to a son who carefully plans the mercy death of his ailing, pain-ridden, terminally ill father. ${ }^{22}$ The premeditation-deliberation formula, if applied seriously, would result in a second-degree conviction of the killer on the bridge, whereas the mercy-killing son would very plausibly be guilty of

15. JOSHUA DRESSLER, UNDERSTANDING CRIMINAL LAW 505-06 (6th ed. 2012).

16. Kitt v. United States, 904 A.2d 348, 353 (D.C. 2006) (emphasis added).

17. State v. Guthrie, 461 S.E.2d 163, 182 (W. Va. 1995).

18. Id.

19. According to Professor Ferzan, in an excellent article on the subject, ten states permit "premeditation to take place as soon as an instant before the action occurs"; "six states allow premeditation to exist instantaneously or simultaneously with the act of homicide," thus taking the pre out of premeditation; whereas nine jurisdictions, either by statute or caselaw, require "an appreciable lapse of time." Kimberly Kessler Ferzan, Plotting Pre-meditation's Demise, 75 LAW \& CONTEMP. PROBS., no. 2, 2012, at 83, 88.

20. E.g., Benjamin N. Cardozo, What Medicine Can Do for Law, in LAW AND LITERATURE AND OTHER ESSAYS AND ADDRESSES 70, 101 (photo reprint 1986) (1999) ("Upon the basis of this fine distinction with its obscure and mystifying psychology, scores of men have gone to their death."); GEORGE P. FLETCHER, RETHINKING CRIMINAL LAW 254 (2000) ("[T] here is obviously a flaw in the criterion of "premeditation and deliberation.' It takes one of several grounds that are sufficient to treat a homicide as among the most wicked, and takes that one ground to be necessary to the exclusion of all others."). Ferzan recently provided a particularly thoughtful critique of the premeditation-deliberation formula. See Ferzan, supra note 19. See generally Matthew A. Pauley, Murder by Premeditation, 36 AM. CRIM. L. REV. 145 (1999) (discussing murder by premeditation). Professor Michael Mannheimer, however, has sought to show that the premeditation-deliberation formula may be justifiable if one focuses on deterrence; people who satisfy the formula, if not necessarily more culpable, are more deterrable. See Mannheimer, supra note 3, at 881.

21. 3 JAMES FITZJAMES STEPHEN, A HISTORY OF THE CRIMINAL LAW OF ENGLAND 94 (Burt Franklin, 1883) (A man, "passing along the road, sees a boy sitting on a bridge over a deep river and, out of mere wanton barbarity, pushes him into it and so drowns him.").

22. See, e.g., State v. Forrest, 362 S.E.2d 252, 254 (N.C. 1987). In that case, Forrest came armed with a gun to the hospital where his critically ill father was hospitalized; crying, and telling his father how much he loved him, he shot his father in the temple, walked into the corridor, dropped the gun, and told others that "[h]e's out of his suffering" and "I killed my daddy." Id. Forrest was convicted of first-degree murder, which was affirmed on appeal. Id. 
first-degree murder. ${ }^{23}$ I, however, would predict that juries, if freed from the premeditation-deliberation formula, would convict the killer on the bridge of first-degree murder and, very possibly, treat the merciful son less severely.

In short, in my model of criminal homicide (and probably in the model of a good number of you in this room), the premeditation-deliberation formula would be abandoned. Intentional killings might constitute firstor second-degree murder, but the degree distinction need have nothing to do with premeditation and deliberation. This is not to say that these concepts, if treated seriously, do not provide insight into issues of culpability, but it does not follow inexorably that one who calmly and thoughtfully kills is always among the most culpable killers deserving of the jurisdiction's most severe penalties; and it is certainly true that those who intentionally kill on a whim are often among the most culpable. ${ }^{24}$

\section{III. “DEPRAVED-HEART” KILLINGS}

My last observation leads directly to my second example of homicide law in need of reform, and back to my view that juries should be given more freedom to draw their own murder-degree distinctions. Is it clear that an intentional killing, even a premeditated one, is always more deserving of punishment than an unintentional one?

Consider common-law "depraved-heart" murder, or what California calls, equally colorfully, "abandoned and malignant heart" murder. ${ }^{25}$ Most states that divide murder into degrees consider this second-degree murder less serious than a "willful, deliberate, and premeditated" killing. ${ }^{26}$ Courts have struggled to explain the meaning of this form of murder to juries. A California court, for example, once said that this form of malice exists "when . . . the defendant for a base, anti-social motive and with wanton disregard for human life, does an act that involves a high degree of probability that it will result in death."27 Later, the same high court re-explained the concept as "an act, the natural consequences of which are dangerous to life, which act was deliberately performed by a person who knows that his conduct endangers the life of

23. As noted in Forrest, the jury did convict the son of first-degree murder, and that conviction was upheld. Id. A decent case can be made that Forrest should only have been convicted of second-degree murder of his father, despite the premeditation of bringing the weapon to the hospital, because his deliberative processes were undermined by deep grief (i.e., this was not a killing "undisturbed by hot blood"). Id.; People v. Morrin, 187 N.W.2d 434, 449 (Mich. Ct. App. 1971). Clearly, however, the killer on the bridge did not premeditate in any serious way, so he would be guilty of second-degree murder in any jurisdiction treating the formula seriously. STEPHEN, supra note 21 , at 94.

24. Ferzan, supra note 19, at 100-01. Professor Ferzan posits that when an actor deliberates for a significant amount of time, there is greater culpability. Id. But, she also believes that, "[a]lthough premeditation can capture some aspects of culpability, it is woefully underinclusive in capturing others." $I d$. at 101 .

25. CaL. Penal CoDE $\S 188$ (West 2014).

26. See MICH. COMP. LAWS ANN. $\$ 750.316(1)$ (a) (West 2014).

27. People v. Thomas, 261 P.2d 1, 7 (Cal. 1953) (en banc) (Traynor, J., concurring). 
another and who acts with conscious disregard for life." ${ }^{28}$ Later still, the California Supreme Court concluded that its first definition was one that juries might have difficulty understanding, so it concluded that instructing the jury by use of the second instruction was "better practice."

But how helpful is the second instruction? Except for the last four words --"conscious disregard for life"- this definition would apply to a doctor conducting perilous surgery. At least the first definition stated that the defendant had to be acting "for a base, anti-social motive and with wanton disregard for human life." ${ }^{30}$ Whatever its other imperfections, does this latter language not come somewhat closer to the idea of what a "depraved" or "malignant" heart killing is all about?

Consider now the Model Penal Code (MPC) approach. Under the MPC, murder occurs if the person kills "recklessly under circumstances manifesting extreme indifference to the value of human life." ${ }^{\prime 31}$ Put more fully, if one consciously disregards a substantial and unjustifiable risk of causing the death of another - that is, kills recklessly-and in so doing manifests an extreme indifference to the value of human life, this is murder rather than manslaughter. ${ }^{32}$

But, does this MPC definition really get to the core of why one is guilty of murder rather than, say, manslaughter if, as a practical joke, he fires a loaded weapon into an occupied room, or uses a bomb to destroy a building she knows is occupied to obtain insurance proceeds, or plays Russian Roulette with a friend? I don't think so. I think the common-law definitions are seeking to tell the jury what an Alabama court explained as "a 'don't give a damn attitude,' in total disregard of the public safety." ${ }^{33}$ Yes, this definition hardly sounds like a lawyerly definition, certainly not like the nearly bloodless MPC definition of recklessness. But, doesn't this tell the jury what the law really means by depraved-heart murder, and doesn't it do the job better than the MPC's approach, in suggesting why some unintentional killings constitute murder? Consider how the high court of New York has explained that state's MPC-like definition:

[D]epraved indifference is best understood as an utter disregard for the value of human life-a willingness to act not because one intends harm, but because one simply doesn't care whether grievous harm results or not. Reflecting wickedness, evil or inhumanity, as manifested by brutal, heinous and despicable acts, depraved indifference is embodied in conduct that is "so wanton, so deficient in a moral sense of concern, so devoid of regard of the

28. People v. Phillips, 414 P.2d 353, 363 (Cal. 1966) (en banc), overruled on other grounds by People v. Flood, 957 P.2d 869 (Cal. 1998).

29. People v. Dellinger, 783 P.2d 200, 205 (Cal. 1989) (en banc).

30. Thomas, 261 P.2d at 7.

31. MODEL PENAL CODE $\S 210.2(1)$ (b) (1962).

32. MODEL PENAL CODE $\S 2.02(2)$ (c) (1962).

33. King v. State, 505 So. $2 d$ 403, 408 (Ala. Crim. App. 1987). 
life or lives of others, and so blameworthy" as to render the actor as culpable as one whose conscious objective is to kill. ${ }^{34}$

What I am getting at here is not that any of these instructions are perfect, but rather that if we are going to follow the traditional view that some unintentional killings should be treated as murder (as I believe we should), then we ought to consider instructing the jury in a way that goes to the heart (no pun intended) of what makes an unintentional killing deserving of treatment as murder. And, I submit that the term "depraved heart"-and New York's explication of the concept-does a better job ${ }^{35}$ than lawyer-like MPC terminology about "substantial and unjustifiable" risk-taking, which is the required first step in characterizing an unintentional killing as murder under the MPC. ${ }^{36}$ Critically, I think our generally shared moral intuition is that someone who demonstrates, by his homicidal act, "wickedness, evil or inhumanity," or whose conduct is "wanton [and] deficient in a moral sense of concern" for others, not only should be convicted of murder, but deserves to be treated as more culpable than some, perhaps many, intentional killers. ${ }^{37}$

Am I concerned about giving a jury an instruction that defines murder in terms of a defendant's "wickedness or evilness" manifested by "heinous or despicable acts"? Yes, it gives me pause because words like "wicked" and "evil" seemingly invite a jury to judge the actor's overall character, which it should not do; we should not punish people because of their bad character or punish them more for that reason. No human being has the wisdom to make such deep judgments about others, least of all jurors, who possess only the facts provided to them at the trial. That is why we should very strictly apply rules limiting the introduction of prior wrongful acts, thus reducing the risk of character attribution. That said, as long as the law is concerned with an actor's state of mind, and particularly when one relevant state of mind is whether a person's unintentional risk-taking "manifest[s an] extreme indifference to the value of human life"--the language of the MPC, which is the essence of the depraved-heart concept - there is no way to entirely avoid the problem. ${ }^{38}$ The risks are diminished, however, as long as jurors are instructed to evaluate wickedness or evilness solely on the basis of the homicidal actions in the present case. ${ }^{39}$ Beyond that concern, I frankly prefer the common law's

34. People v. Suarez, 844 N.E.2d 721, 730 (N.Y. 2005) (per curiam) (quoting People v. Russell, 693 N.E.2d 193, 194 (N.Y. 1998)).

35. Unsurprisingly, some disagree with my observation. E.g., Windham v. State, 602 So. 2 d 798, 80708 (Miss. 1992) (Robertson, J., concurring) (describing "malignity of heart" as a "meaningless metaphor" that "adds nothing of note"; stating that there is "no place" for terms such as "depraved heart" and "malice aforethought" "in a modern criminal code"; and cutely, but I believe wrongly, observing that " [e]vincing a depraved heart' is the puzzler. I doubt it would mean much to a cardiologist").

36. See MODEL PENAL CODE $\S 2.02(2)(\mathrm{c})$.

37. Suarez, 844 N.E.2d at 728 (quoting Russell, 693 N.E.2d at 194).

38. See MODEL PENAL CODE $\S 210.2(1)(b)$ (1962). Indeed, as noted in the next paragraph of the text, it is the essence of murder itself, not just depraved-heart murder.

39. Emphasis on this point ought to be part of any form jury instruction in depraved-heart cases. 
colorful, even emotive, language to what I consider to be the overly-clinical MPC definition of "recklessness," which juries must struggle through before they get to the "extreme indifference" language.

But, I want to go beyond the issue of language. It is worth remembering that what the states of mind included under the umbrella of the common-law term "malice aforethought" (i.e., the intent to kill or cause grievous bodily injury to another person, acting with a depraved heart, or the intent to commit a dangerous felony $)^{40}$ have in common is that they implicate an unjustifiable "person-endangering-state-of-mind." ${ }^{\text {*1 }}$ An even more succinct way of putting this is that what makes the taking of life "murder" is that the actor has, by his actions, (as well-stated by the MPC) manifested an extreme indifference to the value of human life. ${ }^{42}$ Thus, there is no reason why unintentional killings, specifically depraved-heart killings, should inevitably be considered less culpable than, or only as culpable as, intentional ones. The baby killer on the bridge, even if he had no intention of killing the child, manifests a greater indifference to the value of human life than the mercy-killing, loving son. ${ }^{43}$ Affirmative defenses aside, one can easily understand how a jury, if permitted to do so, could find the merciful son less culpable than the baby killer. ${ }^{44}$

So, death-penalty issues aside, perhaps we should let juries decide in a less fettered manner whether a particular unjustifiable killing, intentional or unintentional, should constitute first-degree or second-degree murder, or some other lesser offense.

\section{A TENTATIVE Proposal}

A state should have two degrees of murder, as well as lesser homicide offenses. Murder would be defined as an "unjustifiable killing committed intentionally, or unintentionally under circumstances manifesting an extreme or depraved indifference to the value of human life." 45 The word "recklessness" would not be included in the definition of murder. ${ }^{46}$ The jury would receive an instruction similar to New York's explanation of what constitutes "an extreme

40. The felony-murder rule raises special, controversial issues. In my proposed murder statute, discussed in the next subsection, I would not recognize the rule, as such. But see Suarez, 844 N.E.2d at 728.

41. See Rollin M. PERKINS \& RONALd N. BOYCE, CRIMINAL Law 73 (3d ed. 1982).

42. See MOdel Penal CODE $§ 210.2(1)(b)$.

43. See supra Part II.

44. The son quite arguably was suffering from extreme emotional disturbance, for which there was a "reasonable explanation or excuse," which could justify reduction to manslaughter under the MPC. MODEL. PENAL CODE $\S 210.3(1)(b)$ (1962).

45. A killing during the commission of a felony, particularly an inherently dangerous felony, would often constitute an "extreme or depraved indifference" murder, but the felony-murder rule itself would not be recognized in my proposal.

46. One form of manslaughter might be defined in terms of recklessness, although I am uncertain of this at this time. 
or depraved indifference" killing, ${ }^{47}$ along with an instruction stressing that the jury's function is not to judge the defendant's character as such, but rather to focus solely on the significance of the circumstances relating to the homicidal act charged. Significantly, my proposal would not base the line between firstand second-degree murder on the presence or absence of intent to kill.

So, how would a jury distinguish between levels of murder? I propose that if the jury finds beyond a reasonable doubt that the defendant killed the victim intentionally or as the result of a depraved heart (my shorthand in the current discussion), this would constitute second-degree murder - this would be the default position; however, the jury could raise the charge to first-degree murder if the State proves beyond a reasonable doubt the existence of aggravating factors.

I am not sure what all of the aggravating factors should be, ${ }^{48}$ but they certainly would include factors involving the nature of the victim (e.g., "[t]he victim of the murder was particularly weak, vulnerable, or helpless, ${ }^{, 49}$ public officers killed while in furtherance of their duties, etc.), the motive for the killing, ${ }^{50}$ and the method of the killing (e.g., "[t]he murder was particularly severe, brutal, or cruel"). ${ }^{51}$ I would be inclined to require the existence of at least two aggravating factors to justify a first-degree verdict, particularly if a legislature were to create a long list of aggravating factors. Quite simply, first-degree murder should be reserved for the "worst of the worst" killings. First-degree murders should be the killings that truly stand out.

Would there be a mitigation list to offset aggravating factors? My original thought was that there should not be because second-degree murder is the default verdict in all cases of intentional or depraved-heart killings; thus, the degree of murder is, in a sense, its own mitigation. I am now inclined to think

47. I agree with the Utah Supreme Court that a jury instruction that simply tells jurors to define "depraved heart" in terms of their "experience and common sense" is insufficient. State v. Standiford, 769 P.2d 254, 260-62 (Utah 1988).

48. The aggravating factors would probably look similar to the aggravating factors in capital punishment proceedings, but would result in non-capital punishment. Ferzan provides one original effort at identifying aggravating factors. See Ferzan, supra note 19, at 103-08.

49. See VT. STAT. ANN. tit. 13, § 2303(e)(4) (West 2014), held unconstitutional by State v. Provost, 2005 VT 134, 179 Vt. 337, 896 A.2d 55 (providing a sentencing factor under Vermont law).

50. Because the default is the lesser degree of murder, an aggravating motive would have to be one that is especially egregious, because a killing itself must be egregious simply to justify a finding of second-degree murder. I would think that a "mercy killing" would not aggravate, whereas an unjustified killing committed for money-greed-might aggravate. Thus, the felony-murder rule could come into play if a person intentionally or with depraved heart kills during the commission of a robbery or kidnap for ransom, for example. Similarly, a motive based on hostility toward the victim based on race, religion, sexual orientation, nationality, etc., would likely aggravate. Although one could specify the aggravating motives, I am inclined to favor general language, such as "an especially atrocious or abhorrent motive." Yes, this is a subjective factor, but I find such language less troubling than creating a laundry list of motives to which legislators keep adding new items to the list. Perhaps it is better to leave it to the jurors, as community representatives, to decide what constitutes an especially atrocious motive at any given time.

51. See VT. STAT. ANN. tit. 13, § 2303(e)(5). 
that a mitigating list is appropriate, as long as such a list is carefully crafted. ${ }^{52}$ However one resolves this question, I would definitely incorporate one provision of the MPC in full: a killing that otherwise would constitute murder of either degree would be reduced to manslaughter if the defendant can prove by a preponderance of the evidence that she suffered from an "extreme mental or emotional disturbance for which there is [a] reasonable explanation or excuse." 53 This factor, if proven by the defendant, would override any and all aggravating factors.

Finally, although this goes beyond the scope of my current project, I would note that, to avoid what Jonathan Simon has called the "flattening effect" of murder law-namely, that in some jurisdictions, as a practical matter, only relatively small distinctions in sentences exist between degrees of murder ${ }^{54}$-I would make the range of possible sentences for second-degree murder distinctly less than for first-degree murder. ${ }^{55}$

I repeat, these are preliminary thoughts, and I welcome input. But one final point: the proposal I have described here is what I believe might be the best approach in a theoretically fair trial system. I am as aware as the next person, however, that we do not have such a system. Defendants often have less-than-adequate representation; we have devised a sentencing system that over-punishes, and the guilt phase of trials too often permits prosecutors to give

52. To be clear, "mitigating factors" are not those that negate an aggravating factor, but rather offset it. That is, there may be facts brought out at trial that suggest that the killing does not satisfy one of the specified aggravating factors-or, more accurately, creates a reasonable doubt that the aggravating factor exists. In such circumstances, the aggravation has not been proven, and the killing can constitute no more than second-degree murder, but it is not because there was a mitigating factor.

I would want to be careful not to include certain factors in any mitigation list that are more properly considered at the sentencing phase (for example, that the defendant was abused as a child or comes from a "rotten social background"). If, however, the sentencing authority is (I believe, unwisely) denied discretion to consider such factors, I would necessarily include sentencing factors in the degree-of-murder guilt phase. These matters aside, are there factors that ought to return a first-degree murder verdict to second-degree murder by offset? I now think so. Such mitigating factors would likely include the defendant's youthfulness (although tried as an adult), that the defendant committed the killing for a (jury-determined) good motive, and in multi-party crimes, that the defendant was only a minor participant in the homicide.

53. MODEL PENAL CODE $\S 210.3(1)$ (b) (1962).

54. Jonathan Simon, How Should We Punish Murder?, 94 MARQ. L. REV. 1241, 1247 (2011). Using California as his example, Professor Simon points out that first-degree murder "with special circumstances" carries a penalty of life imprisonment without possibility of parole or death; first-degree murder without special circumstances, carries a sentence of twenty-five-years-to-life; second-degree murder is punished with fifteen years to life with the possibility of parole after fifteen years. "However, in practice, the virtual elimination of executions, and the dramatic reduction in the [number] of persons under a life sentence for murder who actually receive parole (to far fewer than one percent of the eligible pool annually) means that first-degree murder with special circumstances, first-degree murder, and second-degree murder, are all punished with life imprisonment with little or no chance of release." Id. (footnote omitted).

55. As an example, first-degree murder could carry a twenty-five-years-to-life sentence; second-degree murder might be ten to fifteen years; and punishment for manslaughter would obviously be less still. This second-degree sentence may seem lenient, but only if one compares it to the unduly severe sentences that have been meted out in recent decades. Of course, these proposed sentences would require reductions in maximum sentences for other offenses to avoid problems of intra-jurisdictional penal disproportionality. That is why this aspect of homicide law reform goes beyond the scope of my current project. 
jurors a sense of the victim and what he endured at the hands of the defendant, whereas jurors generally do not get a similar sense of the complexities in the defendant's story. ${ }^{56}$ Therefore, my proposal, seeing that it gives juries more discretion in determining the degree of murder than current law, could result in more harsh results than we already experience, although I would greatly mitigate that outcome by reducing the potential maximum sentences available for murder and manslaughter. Perhaps this means my proposal, even if sensible, should wait for other trial and sentencing reforms. That said, I generally trust the jury system, and we cannot, nor should we, make criminal trials bloodless. I believe Sam Pillsbury was right when he observed that "[i]n punishing criminal homicides we use legal doctrines to determine the extent to which the killer disregarded the value of others and so deserves punishment." ${ }^{57}$ It is wrong, then, to think that emotions, including shock or disgust directed at the defendant's conduct, can or should be deterred. Thus, my proposal may make sense even in this real world. Maybe.

56. See generally Thomas III, supra note 6 (relating a criminal trial to a morality play); Lieberman \& Sales, supra note 8 (explaining that jurors may reach decisions inconsistent with the law).

57. Samuel H. Pillsbury, Evil and the Law of Murder, 24 U.C. Davis L. REV. 437, 438 (1990). 